\title{
SAPPHIRINE AND KORNERUPINE OCCURRENCES WITHIN THE FISKENESSET COMPLEX
}

\author{
R. K. Herd
}

Detailed mapping and laboratory studies have been undertaken on rock and mineral associations of the rare magnesium aluminium silicates sapphirine and kornerupine. Their type locality in the southern harbour at Fiskenæsset town was discovered by K. L. Giesecke in 1809 (see Bøggild (1953) for a summary of early investigations). Prior to mapping by GGU and Platinomino A/S geologists in 1970 and 1971, seven localities for sapphirine had been localised within the Fiskenæsset complex (Herd et al., 1969); new discoveries of sapphirine, kornerupine, and (often associated) ruby corundum, have increased the number of known localities to approximately forty.

Information on the geology, petrography, mineral chemistry, and bulk composition of the sapphirine-bearing rocks is given by Herd (1972); this short report is a summary of the most important conclusions from that study.

Many of the sapphirine occurrences at Fiskenæsset can be localised within the stratigraphy of the Fiskenæsset complex. They are found within the topmost portion, constituting a discontinuous horizon between the garnet anorthosites or chromitite-bearing anorthosites of zones 8 and 7 (the uppermost portion of the intrusion; Windley, this issue), and the amphibolites of zone 9. Small occurrences have been found completely within anorthosite, anorthosite with chromitite, and completely within amphibolite.

The Fiskenæsset area underwent at least two periods of regional metamorphism. Evidence of hornblende-granulite facies conditions is preserved in amphibolites and gneisses which have been partially retrogressed to later amphibolite facies assemblages. The granulite facies conditions are not recorded with certainty in the ultramafics, gabbros, and anorthosites of the Fiskenæsset intrusion, because of difficulties in distinguishing high-grade metamorphic from plutonic igneous mineral assemblages. Amphibolite rafts within the intrusive part of the present mappable horizons of the complex suggest that intrusion occurred prior to the granulite facies events, since hypersthene relics occur in such amphibolites, and in the bordering amphibolites of zones 1 and 9 .

The amphibolite facies metamorphism was syn- to post-tectonic with respect to the fold phases which produced interference fold patterns on major and minor scales. The characteristic granoblastic-polygonal textures of the meta-igneous rocks 
of the intrusion were produced during the amphibolite facies equilibration, while greater strain and movement along the borders of the complex produced characteristically lineated fabrics in the amphibolites, and locally within the metaigneous rocks.

There is evidence from study of the (granodioritic or tonalitic) gneisses surrounding the Fiskenæsset complex that a hydrous potash feldspar rich component was mobilised during the amphibolite facies events. Bulk chemical analyses of rocks of the complex show that this mobilised material metasomatised some of the rocks in the upper portion of the intrusion.

The Fiskenæsset intrusion formed by gravity differentiation of a high-alumina basalt magma, and cumulate textures, relict primocrysts, and rhythmic and cryptic layering, can be distinguished. Fractionation occurred under conditions of high water-vapour pressure, causing precipitation of primary amphibole, and suppression of precipitation of chromium concentrations (Shiraki, 1966), which were massively deposited as late chromitite horizons with anorthosite at the top of the intrusion.

The anorthositic material with residual chromium-rich fluids intruded and partially assimilated supracrustal material from the amphibolites (meta-volcanics) of zone 9. Within these amphibolites there was a horizon of highly aluminous magnesian ultramafic material associated with variable amounts of sedimentary rock. This material was also partially assimilated, and provided parental material for the formation of the sapphirine-bearing and associated rocks.

Relict chemical zoning from relatively calcic assemblages next to anorthosite to relatively magnesian assemblages next to amphibolite, can be recognised at many sapphirine localities. The majority of the sapphirine rocks were formed by introduction of the mobilised potash feldspar rich material during amphibolite facies conditions, along the zone of partial assimilation, i. e. along the amphiboliteanorthosite contacts. This metasomatism was accompanied by minor folding accomplished by slip along the contact zone during the major fold events. The concentrations of chromian spinel and ruby corundum found at some localities arise from residual chrome from the Fiskenæsset intrusion; the predominance of phlogopite mica in the sapphirine-bearing and associated rocks shows the effect of the introduced material.

The assimilation of material by anorthosites of the Fiskenæsset intrusion, followed by introduction of potash feldspar, can be proved using a variant of ACF diagrams - the $A^{\prime}$ FS' diagram shown in figure 18. From analyses of sapphirinebearing rocks, molar values of the component oxides were calculated, and the contribution of (anorthite) plagioclase and alkali feldspar to molar $\mathrm{K}_{2} \mathrm{O}, \mathrm{Na}_{2} \mathrm{O}$, $\mathrm{CaO}, \mathrm{Al}_{2} \mathrm{O}_{3}$ and $\mathrm{SiO}_{2}$ values were subtracted as indicated.

The residual bulk compositions plot along two linear zones. The first defines ultramafic rocks composed of variable amounts of orthopyroxene and spinel; the second defines rocks composed of mixtures of spinel and a highly magnesian, 


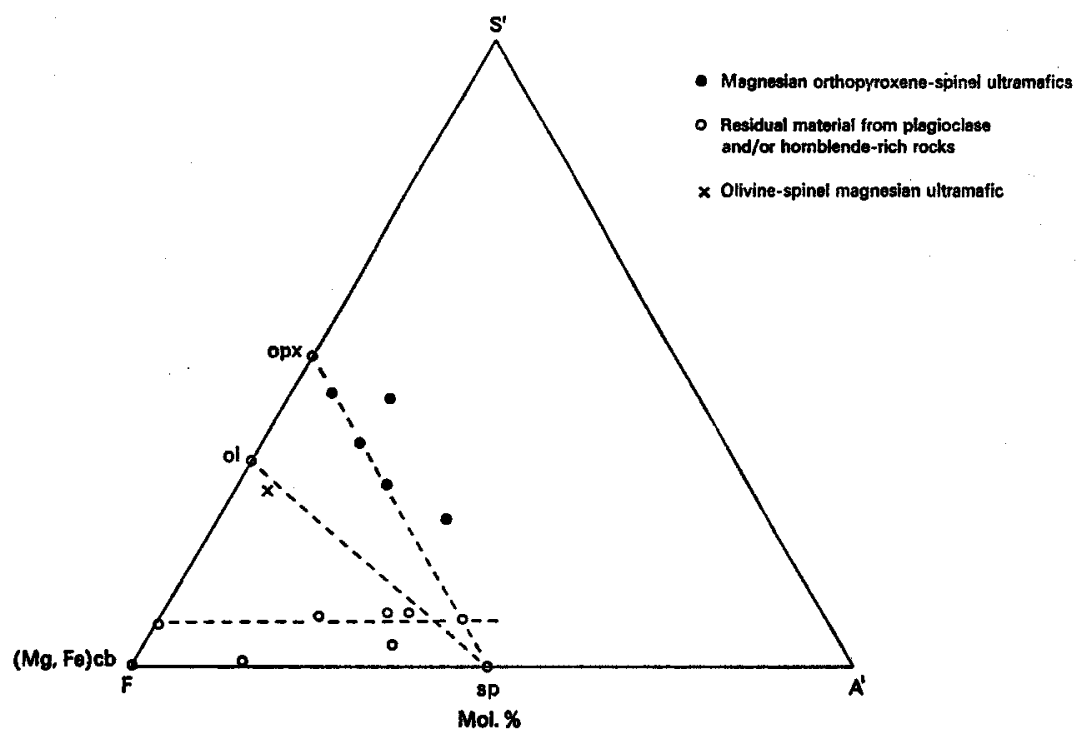

Fig. $18 A^{\prime}$ F $S^{\prime}$ diagram for sapphirine-bearing and associated rocks from the Fiskenæesset region.

$$
\begin{aligned}
& \mathrm{A}^{\prime}=\mathrm{Al}_{2} \mathrm{O}_{3}+\mathrm{Fe}_{2} \mathrm{O}_{3}-\mathrm{Na}_{2} \mathrm{O}-\mathrm{K}_{2} \mathrm{O}-\mathrm{CaO} \\
& \mathrm{F}=\mathrm{FeO}+\mathrm{MgO}+\mathrm{MnO} \\
& \mathrm{S}^{\prime}=\mathrm{SiO}_{2}-2\left(\mathrm{CaO}+3 \mathrm{Na}_{2} \mathrm{O}+3 \mathrm{~K}_{2} \mathrm{O}\right) \\
& \text { All in molar amounts. }
\end{aligned}
$$

low-silica component which is represented by the F corner of the diagram. It is postulated that this component was magnesian carbonate, which generally represents the sedimentary material associated with the magnesian ultramafics and which likewise gave rise to some sapphirine-bearing assemblages.

The chemical data confirm petrographic observations and field mapping. There are four major types of sapphirine-bearing rocks and four major types of associated rocks without sapphirine, these types being characterised by the presence of enstatite, magnesian hornblende, gedrite or phlogopite. For each major rock type, two subtypes can be recognised, one relatively more calcic than the other and showing the presence of abundant plagioclase and/or hornblende. These types are spatially related to the chemical zoning noted during mapping. Mineral assemblages are consistent with the addition of plagioclase and alkali feldspar components to parental material, the components of which were virtually immobile under the prevailing pressure and temperature conditions.

Other associated rocks found at the sapphirine localities are sillimanite-rich layers, calc-silicate rocks grading laterally into forsterite marbles, clintonite-rich rocks, and kornerupine-rich zones. These are interpreted as showing a range of sedimentary rock types from high-alumina laterites or bauxites, through impure 
Table 6. Electron microprobe analyses of sapphirine and kornerupine from the Fiskencesset region

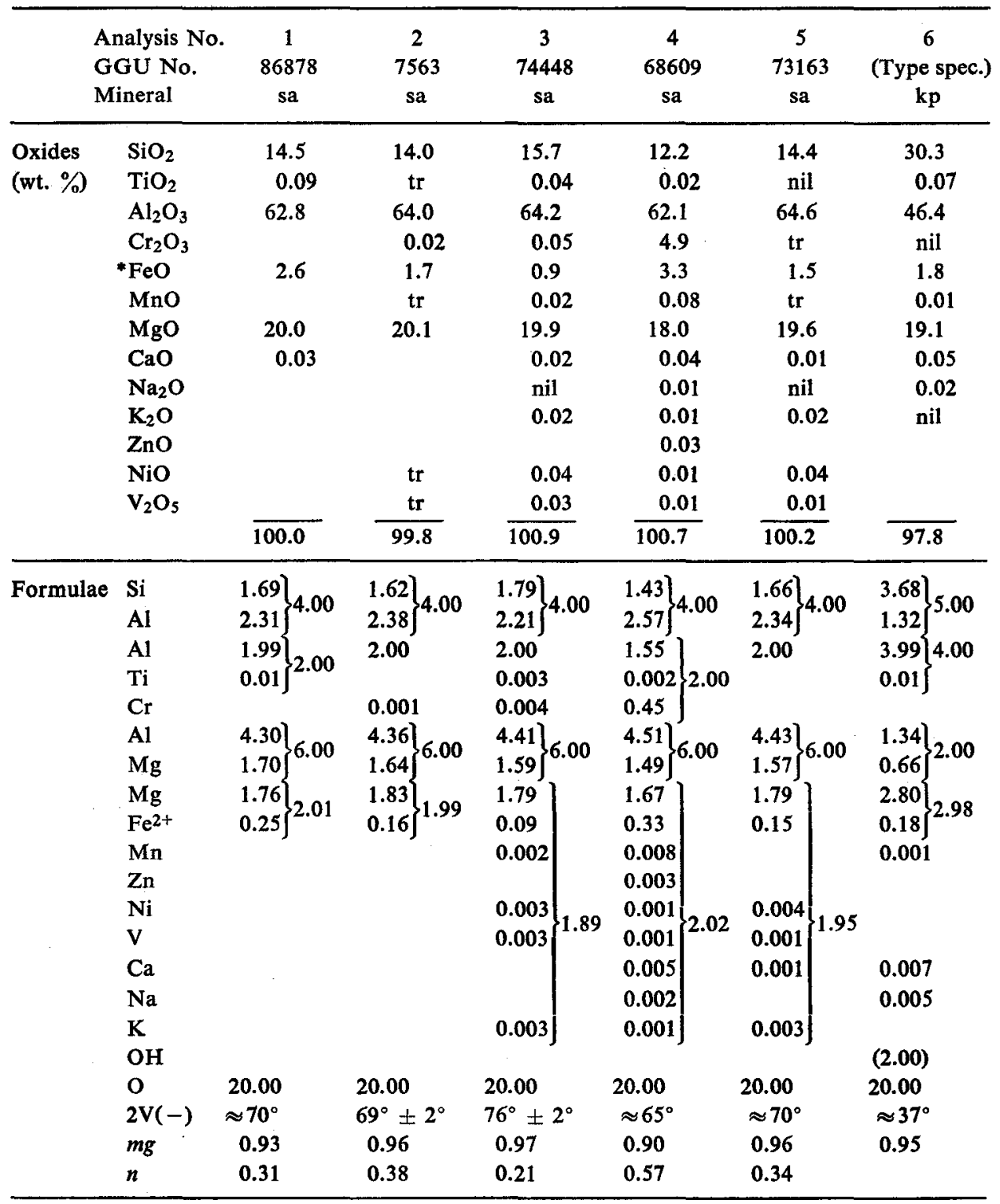

* Total iron as $\mathrm{FeO}$

Notes to table 6

Abbreviations: $\mathrm{sa}=$ sapphirine; $\mathrm{kp}=$ kornerupine; $\mathrm{tr}=$ trace; nil $=$ sought but not detected; $m g=$ Niggli $m g(=\mathrm{Mg} / \mathrm{Mg}+\mathrm{Fe}+\mathrm{Mn}) ; n=2.00$ minus Si value for sapphirine, based on $20(0)$ atoms. 
Precision: Amounts of the major oxides are $\pm 3 \%$ at $95 \%$ confidence limits; minor amounts of oxides are very imprecise (up to $\pm 200 \%$ ) but do indicate the presence of an element in measurable amounts.

Formulae: Summation of cations in formulae for sapphirine and kornerupine is based on new theoretical formulae proposed by Herd (1972).

Analyses: 1. Dark blue sapphirine (subidioblastic) in association with abundant green spinel, enstatite and phlogopite. Fiskenæsset harbour.

2. Pale blue sapphirine lath in association with phlogopite, minor hornblende and plagioclase. Fiskenæsset harbour.

3. Pale blue sapphirine radiating crystal group in association with enstatite, hornblende, pale green spinel, phlogopite, cordierite and magnesian carbonate. Siggartartulik.

4. Greenish gray sapphirine crystal in association with picotite, pink corundum, chromian hornblende, phlogopite, and plagioclase. Lower Angnertussoq.

5. Pale blue sapphirine crystal partially altered to corundum, in association with phlogopite and minor plagioclase. East side of Taseq.

6. Pale brown kornerupine type material from Fiskenæsset harbour (collected by K. J. V. Steenstrup, 1877). Prismatic material occurring with plagioclase, phlogopite, hornblende. Boron was sought but not detected.

All analyses by $\mathbf{R}$. K. Herd. Correction procedures for Geoscan electron probe analyses at Imperial College, London, are outlined by Borley et al. (1971).

(marly) limestones or dolomites, to possible boron-rich evaporites (for kornerupine formation) (cf. Sidorenko, 1970). The whole rock association found within all investigated sapphirine occurrences suggests near-shore marine sediments with associated magnesian ultramafics. Perhaps the best analogue among old Precambrian rocks is the komatiite association of highly magnesian rocks described from the Barberton Mountain Land by Viljoen \& Viljoen (1970). The presence of (rounded) zircon concentrations within spinel, olivine, pyroxene and amphibole from minor layers at the sapphirine localities confirms the existence of a Katarchaean sedimentary sequence pre-dating the intrusion of the Fiskenæsset anorthositic rocks. Zircons have been found in association with chromian spinel and sapphirine in assimilated material.

The mineral phases in some of the rocks have been analysed with a Geoscan electron microprobe, and five analyses of sapphirine and one of kornerupine are given in table 6. In all, 48 analyses are available.

Sapphirine occurs in association with dark green magnesian spinel, or with redbrown picotite, the former arising from metamorphism of the magnesian ultramafics, the latter from partial assimilation of ultramafic or sedimentary material by the chrome-rich anorthosite magma. Enstatite occurs exclusively in association with the magnesian spinel and magnesian sapphirine, and shows $m g$ values from 0.90 to 0.96 . The green spinel has $m g 0.80$ to 0.90 , while the picotite is more iron-rich $(m g$ 0.59) and contains $1.1 \% \mathrm{ZnO}$. Sapphirine developed by replacement from the different types of spinel reflects its origin, in that chromian varieties (see analysis 4) derive from picotite. Other phases analysed include clinoamphiboles which are magnesio-hornblendes and tschermakitic hornblendes in the nomencla- 
ture of Leake (1968) with $\mathrm{mg}$ values of 0.86 to 0.97 . The less magnesian varieties are chromian amphiboles associated with the chromian sapphirine, picotite, and ruby corundum. They show high tetrahedral aluminium in accordance with the predictions of Leake (1971). Gedrites have $m g 0.80$ to 0.90 , phlogopites have $m g .90$ to 0.98 , and may also show traces of chromium in appropriate assemblages. Also investigated were plagioclase (An 90 to 94), cordierite ( $m g$ 0.98 ) and clinochlore ( $m g$ 0.97 , from a magnesian ultramafic in association with spinel and enstatite).

In all, over 45 different mineral phases, including oxides and sulphides as well as silicates, have been recognised from within the sapphirine-bearing rocks. The major phases occur in entirely metamorphic assemblages, characterised by radiating decussate, foliated, and granoblastic-polygonal textures. Most assemblages and textures can be correlated with the syn- to post-tectonic amphibolite facies event, but some of the decussate intergrowths (of both orthopyroxene and amphibole) may record thermal metamorphism during the partial assimilation by the Fiskenæsset intrusion. Evidence of granulite facies events in the sapphirine etc. rocks is confined to granular textures in some of the magnesian ultramafics, within which spinel-enstatite symplectites and olivine porphyroclasts also occur.

Granulite facies conditions were $700-900^{\circ} \mathrm{C}$ with pressures in excess of 7 kilobars, while amphibolite conditions are estimated at $600-700^{\circ} \mathrm{C}$ with pressures of 7-9 kilobars decreasing towards lower pressures during the duration of the amphibolite facies events.

Sapphirine occurs in many forms ranging from rims on spinel, to granoblastic polygonal aggregates with spinel relicts, to contact and interpenetrant twinned, idioblastic aggregates, to porphyroclasts of twinned crystals contained in crush mosaics of small grains, to rims on corundum. Sapphirine colour ranges from pale blue, green, grey, or pinkish grey, to dark blue or greenish blue; purplish varieties have been found. Within the Fiskenæsset area there is a rough correlation between $2 \mathrm{~V}$ values for sapphirine and the parameters $m g$ and $n$ (see table 6). Dispersion in sapphirine $(r<v)$ increases with iron content, as does pleochroism. Very small $2 \mathrm{~V}$ values $\left(c .10^{\circ}\right)$ have been noted for deeply coloured sapphirines. Preliminary X-ray work on specimens from different localities suggests that there may be structural variations which can be related to chemical parameters and physical properties (platy sapphirines with well-developed 010 cleavage have been found).

Kornerupine is now known from six localities in the Fiskenæsset area; it is blue, white, pale brown or greenish in colour and almost always forms columnar radiating aggregates. Some such aggregates have crystals exceeding $50 \mathrm{~cm}$ in length. It is normally accompanied by gedrite, cordierite and phlogopite, but has been found with hornblende and plagioclase. Often kornerupine crystals have been partially replaced by corundum, and in one instance it is altered to sapphirine- 
cordierite symplectites. Kornerupine is considered a mineral of the amphibolite facies in rocks of appropriate composition.

Kornerupine, corundum, olivine and plagioclase have been found to contain $\mathrm{CO}_{2}$-bubble fluid inclusions (Roedder, 1965) indicative of their very fluid-rich environment of formation and alteration. The abundance of such inclusions coupled with rutile inclusions in corundum, and with parting and cleavage in sapphirine, kornerupine, spinel and corundum, makes it doubtful if any of these minerals can be utilised economically.

\section{Acknowledgments}

The writer acknowledges the help and co-operation of GGU geologists T. Frisch, D. Hutt, F. Kalsbeek, T. C. R. Pulvertaft, G. Rivalenti, B. J. Walton, and B. F. Windley, and that of personnel of Platinomino A/S, in the discovery and study of the new sapphirine, kornerupine and ruby localities. Laboratory research has been supported by the Natural Environment Research Council, London, and previously by a Beit Scientific Research Fellowship from the Imperial College of Science and Technology.

\section{References}

Bøggild, O. B. 1953: The mineralogy of Greenland. Meddr Grønland 149, 3, 442 pp.

Borley, G. D., Suddaby, P. \& Scott, P. 1971: Some xenoliths from the alkalic rocks of Teneriffe, Canary Islands. Contr. Miner. Petrol. 31, 102-114.

Herd, R. K. 1972: The petrology of the sapphirine-bearing and associated rocks of the Fiskenæsset complex, West Greenland. Unpubl. Ph. D. thesis, Univ. London, England.

Herd, R. K., Windley B. F. \& Ghisler, M. 1969: The mode of occurence and petrogenesis of the sapphirine-bearing and associated rocks of West Greenland. Rapp. Grønlands geol. Unders. 24, 44 pp.

Leake, B. E. 1968: A catalog of analysed calciferous and subcalciferous amphiboles together with their nomenclature and associated minerals. Spec. Pap. geol. Soc. Am. 98, 210 pp.

Leake, B. E. 1971: On aluminous and edenitic hornblende. Mineralog. Mag. 38, 389-407.

Roedder, E. 1965: Liquid $\mathrm{CO}_{2}$ inclusions in olivine-bearing nodules and phenocrysts from basalts. Amer. Miner. 50, 1746-1782.

Shiraki, K. 1966: Some aspects of the geochemistry of chromium. J. Earth Sci. Nagoya Univ. 14 (1), 10-55.

Sidorenko, A. V. 1970: A unified geohistoric approach to the study of the Precambrian and post-Precambrian. Dokl. Acad. Sci. USSR, Earth Sci. Sect. 186, 36-38.

Viljoen, M. J. \& Viljoen, R. P. 1970: Evidence for the existence of a mobile extrusive peridotitic magma from the Komati Formation of the Onverwacht Group. Spec. Publs geol. Soc. S. Afr. 2, 86-112. 